\title{
Gorontalo
}

Journal of Government and Political Studies

Volume 4 - NO. 1 - April 2021

P-ISSN: 2614-2120 E-ISSN: 2614-2104

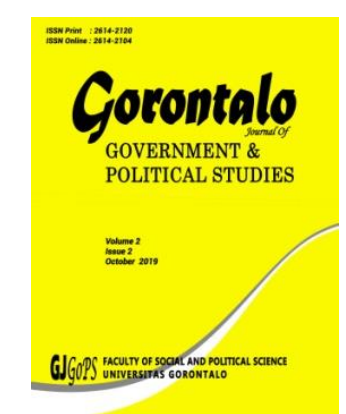

\section{Implementasi Program Rumah Tidak Layak Huni di Kabupaten Karawang}

\author{
Erina Nunung Rohaniati, \\ Rahmat Hidayat, \\ Dewi Noor Azijah \\ Program Studi Ilmu Pemerintahan, Fakultas Ilmu Sosial dan Ilmu Politik \\ Universitas Singaperbangsa Karawang \\ Jalan HS. Ronggo Waluyo, Puseurjaya, Kab. Karawang \\ erinanr9@gmail.com
}

Received: 26th September 2020; Revised: 09th March 2021; Accepted: 18th March 2021

\begin{abstract}
The purpose of this research is to determine the extent of implementation the Unworthy Housing Program in Karawang Regency in order to reduce improper housing and to alleviate poverty. The method of this research is descriptive. Data collection techniques using observation, interviews and documentation. Technical data analysis begins with the preparation of data obtained from interviews and field documentation, data reduction to summarize or select things to focus on, which are important to look for patterns and themes, triangulation to check the validity of the data and for the final results, draw conclusions. . With 7 research informants including 3 people from the Public Housing and Settlement Areas of Karawang Regency, 1 person from Sirnabaya Village and 3 informants who received direct assistance from the RUTILAHU program in Krajan Village Sirnabaya Village, Telukjambe Timur District. Based on the results of the research, the Implementation of the Unworthy Housing Program in Karawang Regency has been going well, but there are still some internal obstacles fulfillment of the requirements criteria so that development cannot be realized evenly.
\end{abstract}

Keywords: housing program, unfit home

ABSTRAK
Tujuan adanya penelitian ini untuk mengetahui sejauh mana Implementasi Program RUTILAHU di Kabupaten Karawang dalam rangka mengurangi hunian yang tidak layak dan untuk mengentaskan kemiskinan. Metode dari penelitian ini ialah deskriptif. Teknik pengumpulan data dengan menggunakan observasi, wawancara dan dokumentasi. Tekhnis analisis data di awali penyusunan data yang diperoleh dari hasil wawancara dan dokumentasi dilapangan, reduksi data untuk merangkum atau memilih hal-hal yang akan di fokuskan yang penting dicari pola dan tema nya, triangulasi untuk mengecek keabsahan data dan untuk hasil selesksi akhir dilakukannya penarikan kesimpulan. Dengan informan penelitan sebanyak 7 orang diantaranya ialah pihak Dinas Perumahan Rakyat dan Kawasan Pemukiman Kabupaten Karawang sebanyak 3 orang, pihak Desa Sirnabaya 1 orang dan dengan para informan yang mendapat bantuan langsung dari program RUTILAHU sebanyak 3 orang yang berada di Kampung Krajan Desa Sirnabaya Kecamatan Telukjambe Timur. Berdasarkan hasil penelitian Implementasi Program Rumah Tidak Layak Huni di Kabupaten Karawang sudah berjalan dengan baik namun 
masih terdapat beberapa hambatan dalam pemenuhan kriteria persyaratan sehingga pembangunan tidak dapat direalisasikan secara merata.

\section{Kata Kunci: program perumahan; rumah tidak layak huni}

\section{PENDAHULUAN}

Pembangunan secara umum ialah proses perubahan yang terus menerus dilakukan untuk mengarah pada perbaikan, pada hakikatnya bertujuan untuk meningkatkan kualitas hidup di suatu negara demi terciptanya kehidupan yang layak dan sejahtera. Maka dari itu pembangunan harus dilakukan secara merata, hal yang mendasar dari pembangunan berarti setiap warna negara berhak memiliki tempat tinggal yang layak. Sesuai dengan kebijakan yang tertera dalam Undang-Undang Dasar Republik Indonesia (UUD R-I) Tahun 1945 Pasal 28H hasil Amandemen ke IV, menyebutkan bahwa "Rumah adalah salah satu hak dasar setiap rakyat Indonesia, maka setiap warga negara berhak untuk bertempat tinggal dan mendapat lingkungan hidup yang baik dan sehat". Namun tidak semua masyarakat Indonesia dapat memenuhi kebutuhan hidupnya dikarenakan keterbatasan ekonomi sehingga tidak bisa membangun rumahnya sendiri.

Rumah adalah salah satu kebutuhan dasar pokok yang dijadikan sebagai tempat berlindung yang secara mental memenuhi rasa kenyamanan, keamanan dan secara sosial dapat menjaga privasi setiap anggota keluarga yang memenuhi standar kesehatan yang baik tidak membahayakan pemiliknya dan sudah seharusnya setiap warga negara bisa mendapati penghidupan yang layak sesuai dengan amanat yang tertuang dalam Undang-Undang Nomor 39 Tahun 1999 Tentang Hak Asasi Manusia pada Pasal 40 dinyatakan bahwa "Setiap orang berhak atas lingkungan hidup yang baik dan sehat". Pemenuhan atas hak perumahan sebagai hak dasar kehidupan manusia. Dalam hal ini pemerintah telah berupaya dalam pemenuhan hak masyarakat dan mengaturnya dalam peraturan Undang-Undangan Nomor 1 Tahun 2011 Tentang Perumahan dan Kawasan Permukiman (UU-PKP) bahwa "Negara bertanggung jawab melindungi segenap bangsa Indonesia melalui penyelenggaraan perumahan dan kawasan permukiman agar masyarakat mampu bertempat tinggal serta menghuni rumah yang layak dan terjangkau di dalam perumahan yang sehat, aman, harmonis dan berkelanjutan di seluruh wilayah Indonesia".

Berdasarkan Peraturan Daerah Kabupaten Karawang Nomor 14 Tahun 2016 tentang Organisasi Perangkat Daerah dan Peraturan Bupati Nomor 11 Tahun 2017 Tentang Perubahan Peraturan Bupati Karawang Nomor 45 Tahun 2016 tentang Kedudukan, Susunan Organisasi, Tugas, Fungsi dan Tata Kerja Dinas Perumahan Rakyat dan Kawasan Pemukiman Kabupaten Karawang, Dalam bagian ke 1 Tugas Pokok pada Pasal 4 bahwa "Dinas mempunyai tugas pokok membantu Bupati melaksanakan urusan pemerintah yang menjadi kewenangan Daerah di bidang PRKP serta tugas pembantuan yang ditugaskan kepada Daerah". Dalam membuat program kerja ini Dinas PRKP tidak terlepas dari keinginan maaupun janji Bupati dan Wakil Bupati terpilih periode Tahun 2016-2021 yaitu "Rehabilitasi RUTILAHU selesai 100\% pada masa periode terpilih melalui pembiayaan dari APBD Kabupaten, APBD Provinsi, APBN dan CSR serta skema pembiayaan yang inovatif (Karawang Bebas RUTILAHU)" yang ada dalam Peraturan Gubernur No. 41 Tahun 2017 Tentang Penyelarasan Penyelenggaraan Rencana Pembangunan Jangka Menengah Daerah Kabupaten Karawang Tahun 2016-2021 yang tertuang dalam 
misi keempat ialah mewujudkan Kabupaten Karawang yang Asri dan Lestari pada tujuan peningkatan kualitas infrastruktur dasar dengan sasaran meningkatnya pengelolaan Kawasan Pemukiman Layak Huni, Strategi nya Penanganan RUTILAHU, dan kebijakan nya berupa Rehabilitasi RUTILAHU. Dan Peraturan Gubernur N0. 38 Tahun 2011 Tentang Bantuan Sosial Pembangunan Rumah Tidak Layak Huni.

Karawang merupakan Kabupaten yang sedang berkembang dalam sektor industrinya namun kemiskinan masih tinggi berdasarkan data BPS Kabupaten Karawang. Secara umum untuk mengetahui persentase peduduk miskin di Kabupaten Karawang dari tahun 2016-2019 dapat dijelaskan dalam tabel berikut:

Tabel 1. Persentase Penduduk Miskin Kabupaten Karawang

\begin{tabular}{c|c}
\hline Tahun & Persentase \\
\hline 2016 & $\mathbf{1 0 , 0 7 \%}$ \\
2017 & $\mathbf{1 0 , 2 5 \%}$ \\
2018 & $\mathbf{8 , 0 6 \%}$ \\
2019 & $\mathbf{7 , 3 9 \%}$ \\
\hline
\end{tabular}

Sumber: Badan Pusat Statistik, Kabupaten Karawang 2019

(Diolah penulis pada 3 Maret 2020)

Dari tabel di atas penduduk Miskin Kabupaten Karawang dari Tahun 2016- 2019 cenderung menurun Pada tahun 2016 terdapat 10,07\% ialah 230.600 jiwa penduduk miskin, ditahun 2017 meningkat dari 10,25\% menjadi 236.840 jiwa, dan pada Tahun 2018 mengalami penurunan menjadi 8,06\% berjumlah 187.960 jiwa, kemudian pada Tahun 2019 menjadi 7,39\% yaitu 173.660 jiwa.

Adanya program RUTILAHU memiliki hambatan misalnya dari setiap pembangunan desa yang tidak merata. Dalam menerima bantuan program ini karena yang mengajukan lebih dari 3 unit/Desa dan Dinas menuntut pihak desa harus lebih selektif memilih siapa yang berhak menerima bantuan ini, karena yang menerima bantuan hanya di beri kuota 3 unit/Desa. Akibatnya timbulah diskriminasi yang tidak dapat dihindari. Mengenai pengajuan proposal untuk pembangunan RUTILAHU melonjak dari Tahun 2018-2019 sebagai berikut:

Tabel 2. Data Rumah Tidak Layak Huni di Kabupaten Karawang

\begin{tabular}{cc}
\hline Tahun & Unit \\
\hline 2018 & 612 \\
\hline 2019 & 2.669 \\
\hline
\end{tabular}

Sumber: Dinas Perumahan Rakyat dan Kawasan Pemukiman,

Kabupaten Karawang 2018-2019 (Diolah penulis pada 4 Maret 2020)

Begitu pesat perkembangan data RUTILAHU di kabupaten Karawang ini, terhitung dari Tahun 2018 ada sebanyak 612 unit dan pada tahun 2019 bertambah menjadi 2.669 unit. Total Periode 2018-2019 adalah 3.281 unit dan proposal yang masuk ke Dinas ada 3.281 unit sedangkan kuota per/Tahun nya hanya diberi jatah membangun 1.200 rumah sisanya akan mendapat penolakan dari Dinas PRKP sebanyak 881 unit yang tidak bisa dibangun. 
Hambatan lain mengenai lamanya proses verifikasi yang dikerjakan oleh pihak Dinas hampir 1 sampai 2 bulan menunggu untuk di tindaklanjuti dan mengenai kelompok sasaran yang tidak puas dengan hasil pembangunan karena rumah dibangun sesuai prosedur pembangunan yaitu dengan ukuran 5x6 meter bukan seseuai dengan luas wilayah tanah yang dimiliki sebelumnya oleh si pemohon, dan standar kelayakan yang masih minimalis, kemudian belum adanya kejelasan mengenai siapa saja instansi yang terlibat dalam pelaksanaan program ini, siapa saja yang ikut bertanggung jawab atas pelaksanaan program ini kemudian sumberdaya nya apa saja yang di butuhkan dalam realisasi pembangunan ini. Oleh karena itu, berdasarkan permasalahan tersebut maka penelitian dimaksudkan akan berupaya mengkaji serta menjelaskan apa saja kendala yang ada di dalam pelaksanaan program RUTILAHU dan bagaimana cara mengatasi kendala tersebut.

\section{METODE PENELITIAN}

Metodologi penelitian ini menggunakan penelitian kualitatif. Peneliti berusaha mendeskripsikan suatu peristiwa. Data yang digunakan dalam penelitian ini berasal dari dua jenis sumber yaitu sumber data primer dan sumber data sekunder. Untuk memperoleh data yang valid dan dapat di percaya maka dalam mengumpulkan data-data yang diperlukan penulis menggunakan teknik pengumpulan obervasi, wawancara, dokumentasi. Teknik analisis data dalam penelitian ini menggunakan analisis deskriptif kualitatif yaitu dengan memberikan ulasan atau interpretasi mengenai data hasil wawancara yang diperoleh sehingga data menjadi lebih jelas. Langkah- langkahnya adalah reduksi data, triangulasi, kemudian penarikan kesimpulan.

Informan dalam penelitian ini ialah mereka yang mempunyai kaitan erat dengan pelaksanaan Implementasi Program RUTILAHU di Kabupaten Karawang, yaitu pihak Dinas PRKP yang berperan sebagai lembaga pemerintah yang mengurusi program ini seperti pada bagian KasuBag Program dan Pelaporan PRKP, Kepala Seksi Bagian Perumahan PRKP, Staff bidang perencana perumahan Dinas PRKP serta pihak Desa yaitu Sekretatsi Desa Sirnabaya, dan dengan masyarakat di Kampung Krajan Rt 02 Rw 01 penerima bantuan Program RUTILAHU dengan dua orang ibu-ibu yang sudah lanjut usia dan menjanda kemudian sengan satu orang bapak-bapak yang sudah tua renta yang memang layak yang sudah memenuhi kriteria pembangunan.

Penelitian dilaksanakan di Kantor Dinas PRKP Gedung Pemda 2 Lt. 2 Jl. Siliwangi. Di Kelurahan Karawang Wetan, Kecamatan Karawang Timur, Kabupaten Karawang, Jawa Barat 41314. Waktu yang digunakan dalam penelitian ini dimulai dari pengumpulan data terlebih dahulu, mengenai informan siapa saja yang akan di teliti kemudian pengelolaan data, reduksi data, serta analisis data selama 4 (empat) Bulan Mulai dari awal Bulan Januari 2020 sampai April 2020.

\section{HASIL DAN PEMBAHASAN}

Hasil penelitian mengenai Implementasi Program Rumah Tidak Layak Huni oleh Dinas Perumahan Rakyat dan Kawasan Pemukiman di Kabupaten Karawang. Sejauh ini sudah berjalan baik meskipun terdapat beberapa kendala yang harus dihadapi oleh pihak Dinas PRKP namun itu tidak menghalangi kinerja mereka. Peneliti telah memutuskan untuk menggunakan teori dari 
"Keberhasilan Implementasi Merilee. S.Grindle (dalam Subarsono, 2013:93)" yang mencangkup 6 variabel diantaranya: kepentingan kelompok sasaran yang mempengaruhi suatu implementasi kebijakan, jenis manfaat yang menunjukkan dampak positif dari implementasi, perubahan yang diinginkan, apakah letak pengambilan keputusan program sudah tepat, apakah sebuah kebijakan telah menyebutkan implementornya dan sumber daya yang memadai, yang dapat peneliti kaitkan dengan data observasi serta wawancara dilapangan, antara lain adalah sebagai berikut:

\subsection{Kepentingan Kelompok Sasaran yang Mempengaruhi Suatu Implementasi Kebijakan}

Para pembuat kebijakan akan berusaha keras mempengaruhi perilaku birokrasi atau pejabat-pejabat lapangan (street level birokrasi bureaucratic) dalam rangka memberi pelayanan atau jasa tertentu atau mengatur perilaku satu atau lebih kelompok sasaran masyarakat. Dalam sebuah kebijakan tentu saja ada yang mempengaruhi berjalannya suatu implementasi, seperti hal nya dalam pelaksanaan program RUTILAHU ini ada pihak BPBD (Badan Penanggulangan Bencana Daerah) yang biasanya mengajukan terlebih dahulu rumah yang memang terkena bencana, meskipun demikian tetap harus melalui prosedur yang ada, Dinas menyarankan kepada BPBD untuk merekomendasikan nya kepada tiap-tiap Desa terkait untuk ikut dalam program pembangunan ini. Dinas mendahulukan laporan yang datang dari BPBD (Badan Penanggulangan Bencana Daerah) yang memang sangat membutuhkan bantuan rumah layak huni ini, dampak dari bencana alam banjir ataupun gempa bumi. Yang dibantu oleh kontraktor bangunan yang akan ikut melancarkan proses pelaksanaan program pembangunan ini.

Namun adapun pihak dinas yang secara terbuka memberitahukan bahwa sengaja adanya BPBD memang untuk membantu Dinas PRKP dilapangan dalam merealisasikan pembangunan rumah layak huni Selaian dari pihak BPBD ada pula dari pihak anggota Dewan yang ikut menunggangi program pembangunan rumah layak huni ini tentu mempengaruhi sasaran kebijakan dari penerima program ini, jelasnya keterangan dari Dinas PRKP Yang membuat pembangunan di satu Desa tidak merata itu karena memang ada anggota dewan yang diberikan anggaran aspirasi dananya itu termasuk dengan dana PoKir (Pokok Pikiran Dewan), untuk anggaran program Rumah Layak Huni yang leading sektor nya adalah PRKP di dalamnya ada dana aspirasi, jadi bukan murni program Dinas PRKP saja. Menanggapi masalah diatas mengenai kepentingan kelompok sasaran yang mempengaruhi suatu implementasi kebijakan yang seharusnya diperankan murni program Dinas PRKP kenyatanya masih belum sesuai dengan ketentuan PerBup Karawang No. 45 Tahun 2016 Tentang Kedudukan, Susunan Organisasi, Tugas, fungsi dan Tata Kerja Dinas PRKP Kabupaten Karawang adalah unsur wajib dalam pemerintah di bidang infrastruktur yang dijadikan solusi untuk terhindar dari kesenjangan sosial. Dalam hal ini berarti dari sisi sasaran kebijakan masih belum merata, karna masih ada campur tangan Dinas dengan beberapa stakeholder. Meskipun demikian Implementasi Program Rumah Layak Huni ini tetap dapat berjalan tanpa adanya komplain dari masyarakat atau instansi lain terkait sasaran kebijakan karena memang tujuan yang dicapai tidak berubah yaitu untuk mengurangi jumlah hunian yang tidak layak di Kabupaten Karawang. 


\subsection{Jenis Manfaat atau Dampak Positif dari Implementasi}

Manfaat dari program RUTILAHU ini di harapkan dapat memberikan hunian yang layak untuk masyarakat yang kurang mampu yang bertempat tinggal dirumah yang sudah tidak layak untuk di tempati, dan meringankan beban mereka yang tidak dapat membangun rumahnya sendiri. Dengan adanya program bantuan ini manfaat yang di rasakan selama empat Tahun terakhir sebanyak 6.478 unit, adanya rekapitulasi pembangunan RUTILAHU oleh Dinas PRKP sesuai Target RPJMD Kabupaten Karawang 2016-2021 adalah sebagai berikut.

Tabel 3. Rekapitulasi Pengalokasian Pembangunan RUTILAHU Dinas PRKP Kabupaten Karawang Tahun 2016-2019

\begin{tabular}{ccc}
\hline No & Tahun & Banyaknya/Unit \\
\hline 1 & 2016 & 516 \\
\hline 2 & 2017 & 1314 \\
\hline 3 & 2018 & 1040 \\
\hline 4 & 2019 & 1243 \\
\hline & Jumlah & $\mathbf{4 1 1 3}$
\end{tabular}

Sumber: Dinas PRKP Kabupaten Karawang, Maret 2020

Rekapitulasi Pembangunan yang sudah di realisasikan dari Tahun 2016 sebanyak 516 unit, di Tahun 2017 sebanyak 1314 unit, di Tahun 2018 sebanyak 1040 unit, kemudian Tahun 2019 sebanyak 1243 unit. Total pembangunan selama 4 Tahun terakhir sebanyak 4113 unit, Dari tabel rekapitulasi di atas Dinas PRKP optimis akan tercapai sesuai target mengingat dengan pembangunan per/tahun yang seharusnya bisa mencapai 1.200 unit, jadi sisa rumah yang harus di bangun sampai Tahun 2021 sebanyak 2.365 unit lagi dari keseluruhan target 6.478 unit. Dilihat dari bagan di atas hal yang mencolok terjadi pada Tahun 2016, yang seharusnya pembangunan bisa mencapai 1.200 unit/Tahun hanya merealisasikan 516 unit . Bila di telaah lagi pembangunan di Tahun 2017 ada 1.314 unit tentu saja melebihi batas pembangunan yang seharusnya 1.200 unit. penyebabnya ada di anggota Dewan yang ikut meramaikan pembangunan Program RUTILAHU, ya bisa dikatakan aspirasi dewan ini terkadang mengalokasikan dana pribadi, dan hasilnya dapat merubah rencana awal. Yang hanya boleh membangun 3 unit untuk satu Desa, malah bisa menjadi 10 sampai 15 rumah yang dibangun. Berikut gambaran rekapitulasi anggaran pembangunan periode 2016-2019:

Tabel 4. Rekapitulasi Anggaran Unit/Cost RUTILAHU Kabupaten Karawang 2016-2019

\begin{tabular}{ccc}
\hline NO & Tahun & Unit/Cost \\
\hline 1 & 2016 & 37.093 .730 \\
\hline 2 & 2017 & 63.363 .775 \\
\hline 3 & 2018 & 41.612 .089 \\
\hline 4 & 2019 & 40.762 .799 \\
\hline
\end{tabular}

Sumber: Dinas PKRP Kabupaten karawang, Maret 2020 
Dari tabel rekapitulasi anggaran per/unit pada Tahun 2016 biaya yang di keluarkan untuk satu rumah sebanyak 37 Juta, di Tahun 2017 melonjak menjadi 63 Juta di karenakan adanya dana aspirasi Dewan, di Tahun 20182019 hampir mencapai 40-41 Juta an, berbanding terbalik dengan kejelasan dari pihak Desa Adanya RAB (Rencana Anggaran Biaya) yang Desa ketahui pihak Dinas itu keluarkan biaya untuk satu unit sebesar 39 Juta-an saja, namun pada kenyataan nya dari banyak nya anggaran tersebut, penerima program ini mengeluh karena rumah baru mereka lantai nya masih plesturan (alas nya semen) tidak diberi keramik, dan atap tidak ada plafon nya.

Dari Target RPJMD 6.478 unit yang sudah dibangun oleh Dinas PRKP sebanyak 4.113 unit selama 4 Tahun terakhir dengan rincian jumlah anggaran keseluruhan 196.345.097.750. Rincian alokasi anggaran pembangunan RUTILAHU dihitung per/Tahun (pagu) mulai dari Tahun 2016 menghabiskan 19.140.364.950 sebayak 516 unit/rumah, lanjut ke Tahun 2017 menghabiskan 83.260.000.000 untuk 1.314 unit/rumah. Kemudian Tahun 2018 menghabiskan 43.276.572.800 untuk pembangunan 1040 unit/rumah dan di Tahun 2019 menghabiskan 50.668.160.000 untuk 1.243 pembangunan, total keseluruhan 196.345.097.750.

Belum termasuk rencana di Tahun 2020 dengan Anggaran 52.172.400.000 untuk realisasi 1.298 unit dengan cost/unit 40.194.453. Yang berarti sisa target di Tahun 2021 adalah 1.067 unit dengan anggaran 41.552.100.000 dengan cost/unit 38.942.924. Dan akan dituntaskan sesuai Target RPJMD yaitu 6,478 unit. Jadi untuk keseluruhan total anggaran di Tahun 2016-2021 dalam rangka pembangunan RUTILAHU ialah sebanyak 290.069.597.750.

Tabel 6. Rekapitulasi Alokasi Anggaran RUTILAHU Tahun 2020

\begin{tabular}{cccc}
\hline NO & Anggaran/Tahun & Unit/Cost & $\begin{array}{c}\text { Banyaknya } \\
\text { (Unit) }\end{array}$ \\
\hline 1 & 52.172 .400 .000 & 40.194 .453 & 1298 \\
\hline & Sumber: Dinas PKRP Kabupaten karawang, Maret 2020
\end{tabular}

Berdasarkan tabel diatas, Rencana anggaran yang akan dikeluarkan di Tahun 2020 sebanyak 52.172.400.000 untuk realisasi 1.298 unit dengan cost/unit 40.194.453

Tabel 7. Rekapitulasi Alokasi Anggaran RUTILAHU Tahun 2021

\begin{tabular}{cccc}
\hline \multicolumn{4}{c}{ SISA TARGET ANGGARAN TAHUN 2021 } \\
\hline NO & Anggaran/Tahun & Unit/Cost & $\begin{array}{c}\text { Banyaknya } \\
\text { (Unit) }\end{array}$ \\
\hline & & 38.942 .924 & 1067 \\
\hline 1 & 41.552 .100 .000 & Sumber: Dinas PKRP Kabupaten karawang, Maret 2020
\end{tabular}


Keterangan tabel di atas mengenai anggaran di Tahun 2021 harus membangun 1.067 unit dengan anggaran sebanyak 41.552.100.000 dengan cost/unit 38.942.924. Dan akan dituntaskan sesuai Target RPJMD yaitu 6,478 unit. Jadi untuk keseluruhan total anggaran tahun 2016-2021 untuk pembangunan RUTILAHU sebanyak 290.069.597.750. Dari berbagai tabel di atas hasil dari Rekapitulasi pembangunan menunjukkan dari Tahun 2016 sampai dengan 2019 sejumlah 4.113 unit, jadi sisa target yang harus di realisasikan sampai 2021 sebanyak 2.365 unit. Dari Target RPJMD 6.478 unit yang sudah dibangun oleh Dinas PRKP sebanyak 4.113 unit selama 4 Tahun terakhir dengan jumlah anggaran 196.345.097.750 Belum termasuk rencana di Tahun 2020 dengan Anggaran 52.172.400.000 untuk realisasi 1.298 unit dengan cost/unit 40.194.453. Yang berarti sisa target di Tahun 2021 adalah 1.067 unit dengan anggaran 41.552.100.000 dengan cost/unit 38.942.924. Dan akan dituntaskan sesuai Target RPJMD yaitu 6,478 unit. Jadi untuk keseluruhan total anggaran tahun 2016-2021 untuk anggaran dana RUTILAHU sebanyak 290.069.597.750.

\subsection{Sejauh Mana Perubahan Yang di Inginkan}

Pelaksana kebijakan memiliki kekuasaan yang besar untuk merealisasikan kebijakan sesuai dengan metodenya sendiri untuk menuju perubahan yang di inginkan, sejak Tahun 2016 sebelum adanya program ini persebaran RUTILAHU di Kabupaten Karawang masih beredar dan belum ada solusi yang tepat untuk menangani nya, dampaknya penyebaran kemiskinan dimana-mana, namun kini setelah adanya program pembangunan RUTILAHU ini di harapkan dapat meminimalisir kesenjangan sosial masyarakat di Kabupaten Karawang dan diharapkan dapat memberikan hunian yang layak kepada masyarakat yang kurang mampu. Meskipun demikian bisa di artikan bahwa pembangunan RUTILAHU belum sepenuhnya merata, sesuai dengan rekapitulasi per/Kelurahan atau Desa yang tersebar di Kabupaten Karawang dari Tahun 2016 hingga tahun 2019.

Hasil dari rekapitulasi pembangunan RUTILAHU pada tahun 2016 masih sedikit yaitu hanya ada 516 unit rumah yang dibangun oleh pihak Dinas PRKP, yang dimana itu kurang dari capaian target pertahun yang seharusnya 1.200 unit rumah. Hasil dari rekapitulasi pembangunan RUTILAHU pada tahun 2017 sebanyak 1314 unit rumah yang di bangun oleh pihak Dinas PRKP, pembangunan tersebut melebihi dari capaian target perTahun yang seharusnya 1.200 unit. Akumulasi dari Tahun 2016 ke Tahun 2017 ada peningkatan pembangunan sebanyak 798 unit. Hasil dari rekapitulasi pembangunan RUTILAHU pada tahun 2018 sebanyak 1040 unit rumah yang mendapat bantuan dari pihak Dinas PRKP kurang dari capaian target. Kemudian di Tahun 2018 ada penurunan yang seharusnya di bangun 1.200 unit hanya di bangun 1040 rumah saja. Hasil dari rekapitulasi pembangunan RUTILAHU pada tahun 2019 sebanyak 1243 unit rumah yang mendapat bantuan pembangunan dari pihak Dinas Perumahan Rakyat dan kawasan Pemukiman, melebihi dari capaian target perTahun yang seharusnya 1.200 unit rumah. Dapat disimpulkan mengenai rekapitulasi pembangunan yang sudah direalisasikan oleh Dinas PRKP sebanyak 3.668 unit rumah. 


\subsection{Letak Pengambilan Keputusan Program}

Selain memenuhi persyaratan dan ketentuan yang berlaku, agar bisa menjadi Calon Penerima Bantuan program ini sasaran kegiatan pemberian bantuan haruslah masyarakat miskin yang menempati hunian yang tidak layak huni dan hasil pendataan oleh pemerintah Desa setempat kemudian di survey bahwa bangunan tersebut memang layak untuk dibantu dengan catatan persyaratan nya memenuhi barulah dimasukkan kedalam daftar nominasi penerima bantuan dari pihak Dinas PRKP selaku panitia pelaksana Program RULAHU, setelah di survey kemudian di masukkan kedalam daftar usulan, pada saat tahun anggaran turun barulah pihak Dinas memverifikasi kemasing-masing calon penerima bantuan.

Adapun Karakteristik rumah yang akan di renovasi yaitu mekanisme pengajuan RUTILAHU pertama adalah pihak pemilik mengajukan kepihak desa, dari desa mengajukan lagi ke dinas dengan persyaratan dengan melampirkan fotokopi KTP, fotokopi KK, legalitas hak atas tanah, Surat Tanah, SKTM (Surat Keterangan Tidak Mampu), Surat permohonan dari Kepala Desa, Foto fisik kondisi bangunan rumah pada saat diusulkan. Untuk pengajuan, Desa lah yang mengajukan ke dinas, nantinya jika sudah di ajukan, dinas akan mensurvey ke rumah-rumah yang telah di ajukan oleh Desa untuk mengecek apakah benar kriterianya sudah sesuai dengan persyaratan. Biasanya yang diajukan oleh desa itu hanya sebidang tanah yang sebelumnya tidak ada bangunannya. Adapula yang memang di ajukan itu ialah tanah yang bukan milik hak pribadi yang tidak ada bukti sertifikat kepemilikan tanah tersebut. Karena jika tidak sesuai ketentuan sudah dipastikan proposal permohonan tersebut akan ditolak oleh pihak Dinas PRKP. Kemudian mengenai proses pengajuan untuk calon penerima bantuan yaitu pemohon mengajukan ke Kepala Desa setempat, dilanjut Kepala Desa mengajukan ke Dinas Perumahan Rakyat dan Kawasan Pemukiman tepat nya ke bagian Bidang Perumahan, lalu pengajuan ditindak lanjuti Kemudian apabila persyaratan sudah memenuhi kriteria, selanjutnya pihak Dinas terjun langsung untuk survey ke lapangan agar mengetahui keadaan kondisi rumah yang sebenarnya.

\subsection{Sebuah Kebijakan Menyebutkan Implementornya}

Didalam suatu kebijakan tentu harus ada penanggung jawab atas pelaksanaan program yang akan di realisasikan, dalam program pembanguan RUTILAHU disini pun ada pihak Dinas PRKP yang telah membagi tugas untuk team survey, di dalam pelaksanaan pembangunan di tiap Kecamatan ada 1 team yang terdiri dari 3 orang yang akan mensurvey langsung ke lapangan, dan mengawasi pembangunan mulai dari pengukuran lahan, pengecekan bahan material bangunan sampai dengan pembangunan rumah dari hari pertama hingga penyerahan kunci kepada pemilik rumah.

\subsection{Sumber Daya Yang Memadai}

Sumber daya seperti kemampuan manusia, kesiapan dana, teknologi dan fasilitas yang menunjang tentu saja akan sangat membantu pelaksanaan program pembangunan RUTILAHU di Kabupaten Karawang, dalam hal ini Dinas PRKP Kabupaten Karawang membutuhkan segala fasilitas yang akan menunjang kelancaran pelaksanaan program ini sepeti kendaraan Dinas untuk mensurvey lokasi yang akan di cek kebernarannya, Meteran pengukur, dan aplikasi camera 
Geo Camp untuk pegukuran secara detail. Dan disini Dinas PRKP telah menyiapkan segala sesuatu nya demi kelancaran pembangunan program RUTILAHU. Pihak Dinas melakukan survey dan pengecekan, mulai dari awal pengajuan sampai selesai saat penyerahan kunci, sehingga pihak Desa ikut serta melancarkan pelaksanaan ini dan kadang ikut mengawasi kontraktor saat melakukan pembangunan.

Hambatan yang di alami oleh Dinas PRKP ialah di sayangkan pihak Dinas tidak bisa setiap hari mengawasi pembangunan yang dilakukan oleh kontraktor, karna team survey harus membagi waktunya untuk memantau tempat lain, dan hambatan pada saat pelaksanaan rumah yang akan di bangun berada di gang kecil yang membuat para pekerja kontraktor susah mengangkut-angkut bahan bangunan yang harus memerlukan bantuan tenaga dari pihak masyarakat setempat, Perlu digaris bawahi disini Dinas harus meningkatkan kinerja nya termasuk saat pelaksanaan pembangunan yang sedang berlangsung, supaya tidak ada kecurangan yang di manfaatkan oleh oknum kontraktor seperti pengurangan bahan bangunan material. Hambatan lain pun muncul ketika pihak Desa mengusulkan calon penerima bantuan yang secara fisik memang harus di bantu namun kenyataan nya secara persyaratan tidak memenuhi mulai dari Tanah yang tidak bersertifikat/ tanah bukan hak milik, sehingga pihak Dinas tidak bisa merealisasikan pembangunan tersebut.

\section{PENUTUP}

Berdasarkan hasil penelitian di atas maka ditarik simpulan bahwa Dinas PRKP Kabupaten Karawang telah melaksanakan program RUTILAHU ini sejak Tahun 2016 hingga sekarang. Dalam pelaksanaan nya sudah berjalan cukup baik terbukti dalam hal ini pihak Dinas PRKP sudah merealisasikan hampir 90\% unit/rumah. Adanya Kerjasama Dinas PRKP dengan beberapa stakeholder yaitu dengan pihak BPBD (Badan Penanggulangan Bencana Daerah) yang biasanya mengajukan terlebih dahulu rumah yang memang terkena bencana dan tetap harus melalui prosedur yang ada, kemudian pihak Desa yang bersangkutan dan kontraktor bangunan. Ada pula dari pihak anggota Dewan yang ikut menunggangi program pembangunan rumah tidak layak huni yang tentu mempengaruhi sasaran kebijakan dari penerima program ini. Pihak Dinas PRKP telah membagi tugas tim survei di Kabupaten Karawang, di tiap Kecamatan ada 1 tim yang terdiri dari 3 orang dan adanya fasilitas yang menunjang demi kelancaran pelaksanaan program ini sepeti kendaraan Dinas untuk mensurvey lokasi, Meteran pengukur, dan aplikasi camera Geo Camp untuk pegukuran secara detail.

Pelaksanaan program pembangunan RUTILAHU ini cukup membantu masyarakat yang kurang mampu yang ada di Kabupaten Karawang khusunya untuk mereka yang tidak memiliki rumah yang layak untuk ditempati. Namun peneliti tetap memiliki rekomendasi untuk pihak dinas dan pemerintah dalam implementasi program RUTILAHU di Kabupaten Karawang demi kelancaran nya kebijakan ialah sebagai berikut:

1. Dalam rangka memberikan pelayanan atau jasa tertentu kepada masyarakat sudah seharusnya pemerintah dapat berlaku adil juga bijaksana tanpa terpengaruhi atau paksaan dari pihak manapun. Agar tidak ada Diskrimanasi sosial di dalam menjalankan kebijakan nya.

2. Dalam penerapan dari Program Pembangunan Rumah Tidak Layak Huni oleh 
Dinas Perumahan Rakyat dan Kawasan Pemukiman di Kabupaten Karawang kinerja pihak Dinas harus ditingkatkan lagi agar bisa merealisasikan program ini sesuai target RPJMD Kabupaten Karawang yaitu membangun 6,478 unit sampai tahun 2021.

3. dari keterangan rekapitulasi anggaran per/unit pada Tahun 2016 biaya yang di keluarkan untuk satu rumah sebanyak 37 Juta, di Tahun 2017 melonjak menjadi 63 Juta karena dana aspirasi Dewan, kemudian di Tahun 2018-2019 mencapai angka 40-41 Juta'an. Sudah seharusnya uang anggaran ini dapat diberikan secara merata tanpa di beda-bedakan, agar masyarakat mendapatkan manfaat yang sama dari pembangunan RUTILAHU ini.

4. Di harapkan dengan adanya program RUTILAHU ini Pemerintah bisa meminimalisir kesenjangan sosial yang ada dan bisa memberikan hunian layak kepada masyarakat yang kurang mampu di Kabupaten Karawang. Pemerintah hendaknya memberikan edukasi atau arahan melalui sosialisasi kepada masyarakat, desa-desa dan instansi pemerintah dengan lebih jelas mengenai program pembangunanRUTILAHU.

5. Diharapkan masyarakat bisa memberikan masukan atau ide-ide baru kepada pemerintah terkait program pembanguan RUTILAHU agar pelaksanaan nya dapat maksimal.

6. Dinas PRKP Kabupaten Karawang harus bisa memfasilitasi untuk menunjang kelancaran pelaksanaan program RUTILAHU.

\section{DAFTAR PUSTAKA}

Moleong, Lexy J. 2017. Metodologi Penelitian Kualitatif. Bandung: PT Remaja Rosdakarya. Cet ke-36 Hal: 11 dan 330

Purwanto E.A and Sulistyastuti D.R 2015. Implementasi kebijakan Publik: Konsep dan Aplikasinya di Indonesia. Yogyakarta:Penerbit GAVA MEDIA Cet ke-2 Hal $20 \& 21$

Purwanto E.A and Sulistyastuti D.R 2015. Implementasi kebijakan Publik: Konsep dan Aplikasinya di Indonesia. Yogyakarta:Penerbit GAVA MEDIA Cet ke-2 Hal 125

Subarsono, AG, 2013 Analisis Kebijakan Publik, Pustaka Pelajar, Yogyakarta.Hal. 8

Subarsono, AG, 2013 Analisis Kebijakan Publik, Pustaka Pelajar, Yogyakarta.Hal. 90, 93,94, 99

Sugiyono, 2018. Metode Penelitian Kuantitatif, Kualitatif, dan R\&D. Bandung: Alfabeta. Cet ke-26 Hal: 137, 244, 245, 247

Winarno, Budi, 2012. Kebijakan Publik, teori, proses dan studi kasus, CAPS, Yogyakarta. Hal 146, $148 \& 149$

Peraturan Bupati (PerGub) Karawang No.41 Tahun 2017 tentang Penyelarasan Rencana Pembangunan Jangka Menengah Daerah Kabupaten Karawang Tahun 2016-2021

Peraturan Bupati (PerGub) Karawang Nomor 45 Tahun 2016 tentang Kedudukan, Susunan Organisasi, Fungsi dan Tata Kerja Dinas Perumahan Rakyat dan Kawasan Pemukiman Kabupaten Karawang

Peraturan Menteri Negara Perumahan Rakyat Republik Indonesia Nomor 22/Permen/M/2008 tentang Standar Pelayanan Minimal Bidang Perumahan Rakyat Daerah Provinsi dan Daerah Kabupaten/Kota 
Peraturan Undang-Undang No.1 Tahun 2011 tentang Perumahan dan Kawasan Pemukiman dalam (UU-PKP)

Rencana dari Strategis Dinas Perumahan Rakyat dan Kawasan Pemukiman Kabupaten Karawang 2016-2021. Hal. 28

Rencana dari Strategis Dinas Perumahan Rakyat dan Kawasan Pemukiman Kabupaten Karawang 2016-2021. Hal. 37

Rencana dari Strategis Dinas Perumahan Rakyat dan Kawasan Pemukiman Kabupaten Karawang 2016-2021. Hal. 48-49

Undang-Undang Dasar RI Tahun 1945, di pasal 28H hasil amandemen ke IV, Dasar hukum dan kriteria rutilahu

Undang-Undang Nomor.39 Tahun 1999 tentang Hak Asasi Manusia pada pasal 40 dinyatakan bahwa "setiap orang berhak untuk bertempat tinggal serta berkehidupan yang layak.

http://www.kabaredemak.com/2017/03/apa-itu-rs-rtlh-program-kemensosuntuk.html (di akes pada Kamis, 10 Februari 2020)

https://akurat.co/ekonomi/id-1027448-read-rumah-layak-huni-yang-idealmasih-jadi-permasalahan-keluarga-muda (di akses Jumat 14 Februari 2020)

https://databoks.katadata.co.id/datapublish/2019/10/17/inilah-persebaranrumah-" tangga-kumuh-di-indonesia (di akses Jumat 14 Februari 2020) 